\title{
DEVELOPMENT OF THE INFORMATION ECONOMY UNDER THE CONDITIONS OF GLOBAL ECONOMIC TRANSFORMATIONS: FEATURES, FACTORS AND PROSPECTS
}

\author{
Nataliia Trushkina
}

\begin{abstract}
The article provides a content structure of the information economy, including the main components and factors of the development. The factors of influence on the development of the information economy are identified. They are conditionally classified into five groups: research and development in the field of ICT; employee component; ICT sector development; digital technologies in business; information security. The dynamics of the development indicators of the information economy is analyzed. Prospective lines of the development of the information economy in the global cyberspace are identified, including the creation of a digital platform as a new business model; using the concept of Industry 4.0 and the "smart factory" as drivers for the digital transformation of industrial development; implementation of the "cyber physical system" as a single complex of information resources, systems and physical processes. A formula is proposed for evaluating the effect of the information economy development.
\end{abstract}

Keywords: information economy, features, conceptual approaches, factors, components, prospects, digital technologies

JEL Classification: A10, B30, D80, L86

\section{Author:}

\section{Nataliia Trushkina}

Institute of Industrial Economics of National Academy of Sciences of Ukraine, 2 Marii Kapnist Street, Kyiv, Ukraine, 03057

E-mail:nata_tru@ukr.net

https://orcid.org/0000-0002-6741-7738

Citation: Trushkina, N. (2019). Development of the information economy under the conditions of global economic transformations: features, factors and prospects. Virtual Economics, 2(4), 7-25. https://doi.org/10.34021/ve.2019.02.04(1)

Received: June 23, 2019. Revised: August 3, 2019. Accepted: September 9, 2019.

(C) Author(s) 2019. Licensed under the Creative Commons License - Attribution 4.0 International (CC BY 4.0) 


\section{Introduction}

The information economy is one of the prospective lines of development of national economies of different countries in the global cyberspace. The main backgrounds for the formation and rapid development of a new type of social relations are, first of all: globalization of the world economy and integration of world capital markets; transnationalization of innovative production; transformation of business practices and company building; change in the capital structure of the company; increased competition and differentiation of companies; organizational structure innovation; application of digital technologies; activation of e-business and e-commerce.

McKinsey Global Institute experts (Boden et al., 2010) claim that the process of developing the information (digital) economy is comparable in scale to the industrial revolution of the 18th19th centuries, which radically changed the whole world, giving many countries a rise for economic growth, changing the development model itself.

The current transition to an information economy is becoming a key factor in GDP growth. This is due to not only the effect obtained from the automation of existing processes, but also from the introduction of new, breakthrough business models and technologies, including digital platforms, digital ecosystems, in-depth analytics of large data arrays, technologies "Industry 4.0".

Review and generalisation of scientific literature confirm the relevance of various aspects of the development problem of the information economy. Scientists pay considerable attention to the formation of evolutionary views on the conceptual apparatus, the study of modern trends and the identification of prospective lines of development of the information economy. At the same time, the versatility, multidimensionality, and argumentation possibility of individual issues on the chosen topic necessitates further scientific research.

The aim of the article is to study features and identify factors that influence the development of the information economy; identification of prospective lines in the context of global economic transformations.

\section{Literature review}

Review of the field-specific literature shows that there is no single scientific approach to the definition of the term "information economy". It was found that researchers use many concepts to determine the conceptual meaning of the information economy (Figure 1).

The use of the term "new economy" was quite popular in the scientific literature, the first mention of which dates back to 1898, when L. Gronlund in his work "The New Economy. A Peaceable Solution of the Social Problem" (Gronlund, 1898) pointed out the need for social transformation and defined the new economy as the economy of the dominance of collectivism. 
After that, the essentially similar concept of "knowledge economy" proposed by F. Machlup (Fritz Machlup) in his work "The Production and Distribution of Knowledge in the United States" (Machlup, 1962) was used in literature. Later, the concept of "digital economy" was introduced into scientific turnabout as a virtual economic system, the founder of which is $D$. Tapscott (Tapscott, 1996).

The term "information economy" was first formulated in 1976 by M. Porat (Marc Uri Porat), who conducted in his dissertation a study in his dissertation, and predicted a rapid transition from classical production capital to intellectual property, that is, the production of information (Porat, 1977).

According to D. Tapscott and E. Williams (2009), it is the information (intangible assets, licenses, patents, technologies, know-how expressed in a specific form) that plays the largest part in the information economy, rather than knowledge representing an abstract category. Nevertheless, information and knowledge are in dialectical unity, which means they are permanently and organically interconnected.

The concept of the information economy includes a fundamental definition of the information society as a system of connections and relationships between individuals, which is formed in the process of exchanging information on social and economic activities. The information economy is significantly different in nature from the "goods economy" and forms new social relations that arise through the use of new information technologies (networks), and is accompanied by transformations of the industrial relations of an industrial society (Pidoymo \& Buturlakina, 2010).
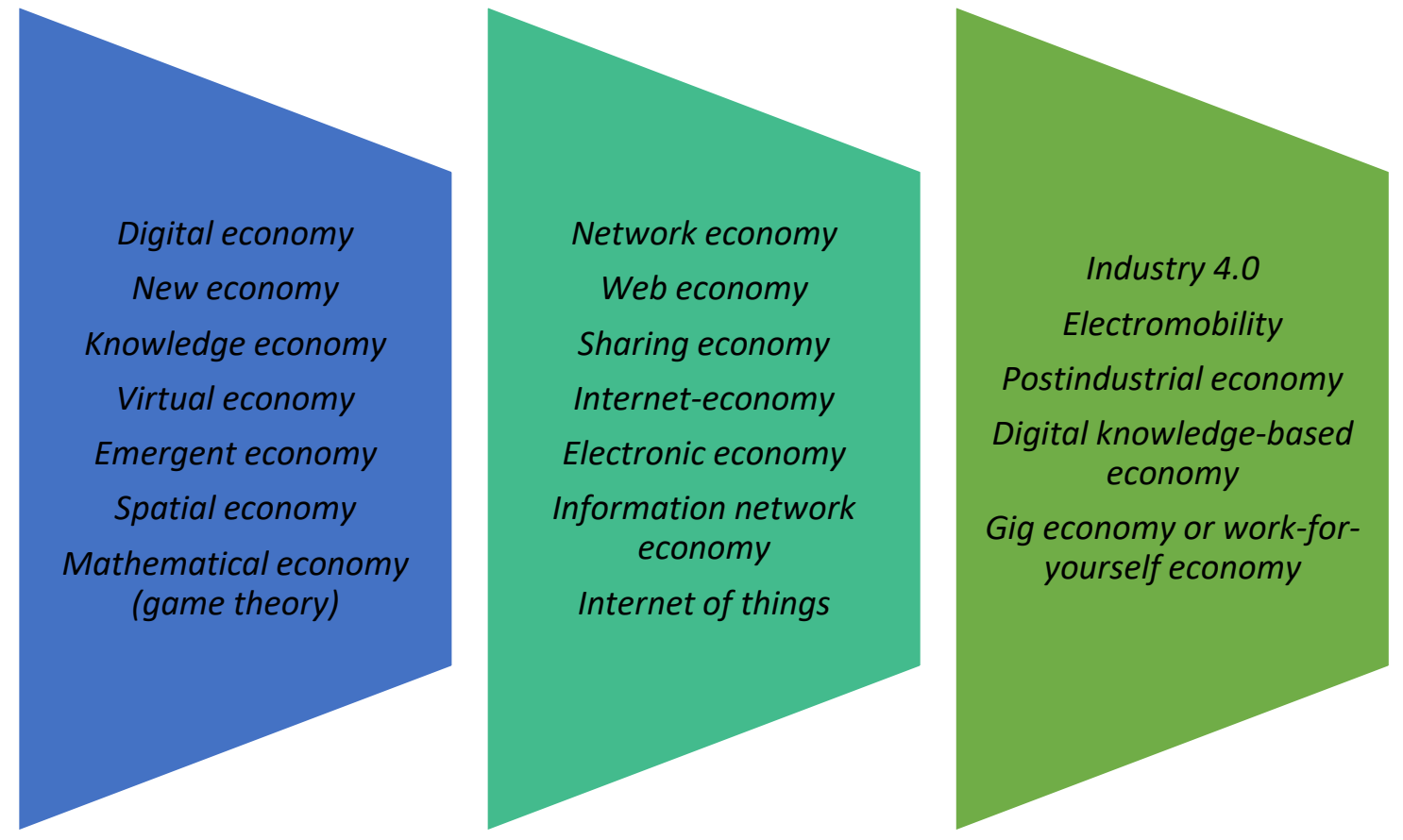

Figure 1. Terms that identify the concept of "information economy" Source: own research. 
In literature sources there are numerous formulations of concepts related to the information economy: the new economy (Pashkus, 2006; Chumachenko, 2014; Belotserkovets, 2015; Dzwigol, 2019); information and network economy (Dyatlov, Maryanenko, Selishcheva, 2016; Kuzior et al., 2019; Kwilinski et al., 2019a; 2019b; 2019c; Lakhno et al., 2018; Pajak et al., 2016 Tkachenko et al., 2019a; 2019b; 2019c; 2019d); network economy (Chumachenko, 2014); digital economy (Tapscott, 1996; Lane, 1999; Margherio et al., 1999; Brynjolfsson \& Kahin, 2000; Mesenbourg, 2001; Machlup, 2014; Kit, 2014; Tugui, 2015; Apalkova, 2015; Elmasry et al., 2016 ; Knickrehm, Berthon \& Daugherty, 2016; Bahl, 2016; Dahlman, Mealy \& Wermelinger, 2016; Kolyadenko, 2016; Teslenko, 2016; Panshin, 2016; Bukh \& Heeks, 2017; Baranov, 2018; Gudz, 2018); information economy (Machlup, 1973; Pidoymo \& Buturlakina, 2010; Chumachenko, 2014; Shkarlet, 2014; Matveeva \& Khomenko, 2017).

The definition of any given concept is a reflection of time and contemporary trends. Early interpretations put Internet technologies at the forefront, which became a kind of technological mainstream of the 1990s. The authors of later definitions pay attention to the development of mobile and wireless networks, as well as cloud technologies and technologies for working with big data, or turn to a more general concept of digital technologies. The term "new economy" was used for some time at the turn of the century, but was not very popular. The network economy as a concept is much more "survivable," but its definition is much more complicated than the digital economy, since the main focus is not on technology, but on structural changes.

Brynjolfsson, Kahin (2000) stated that the definition of "information economy" has acquired the meaning of a broad, long-term trend for the further expansion of assets based on information and knowledge, as well as the value associated with real assets and products.

Bukh, Heeks (2017) systematized the existing concepts of "digital economy", identifying 4 approaches that have their own particular characteristics: resource-based approach is based on technology, information resources, that is, data processing (Brynjolfsson, Kahin, 2000), as well as human resources, that is, human knowledge and creativity, arising from information and communication technologies (Tapscott, 1996); process approach is the use of technology for business operations (Kling, Lamb, 2000; Mesenborg, 2001); new streams of information and data generated through ICT (Lane, 1999); ongoing transformations in technological processes (Bahl, 2016); structural approach includes, as components of the digital economy, the transformation process (Brynjolfsson, Kahin, 2000) and developing structures based on web (network) technologies; business-based approach - as components of the digital economy, new emerging business models are considered, that is, network business and electronic commerce (Mesenborg, 2001) or digital platforms.

Thus, the review shows that most researchers identify the information economy with the digital one, which includes a type of economic system where the predominant part of the national product is provided by activities that are somehow related to the production, processing, storage and distribution of information. 
It should be noted that some scientists prefer to talk about the digital economy, the most important component of which is a sufficient level of technology used, transforming the relationship between business entities, changing the paradigm towards the development of flexible schemes for organizing the economy, where coordination occurs through digital technologies. In other definitions, in addition to economic activity, the social sphere is affected. Still others focus on the factor of technological development of the production structure and the growing role of information and communications in the process of performing economic activities.

\section{Methods}

As a result of the study, many existing scientific points of view on the interpretation of the information economy are summarized (Table 1).

Table 1. Systematization of scientific approaches to the definition of the concept of "information economy"

\begin{tabular}{|c|c|}
\hline Classification group & Contents \\
\hline Science & $\begin{array}{l}\text { the science of studying the economic theory of the modern information society; } \\
\text { the science that studies the patterns of using informational factors as } \\
\text { components of an ecosystem; } \\
\text { scientific field in economy, studying the influence of information on economic } \\
\text { decisions }\end{array}$ \\
\hline $\begin{array}{l}\text { A new type } \\
\text { of economy }\end{array}$ & $\begin{array}{l}\text { economy based on network services; } \\
\text { economy created on a new technological basis; } \\
\text { economy based on digital technologies; } \\
\text { a type of economy characterized by the active introduction and practical use of } \\
\text { digital technologies; } \\
\text { emergent economy existing in virtual reality; } \\
\text { economy operating on electronic goods and services }\end{array}$ \\
\hline $\begin{array}{c}\text { Section of economic } \\
\text { theory }\end{array}$ & $\begin{array}{l}\text { section of economic theory, where the object of research is the economy of the } \\
\text { information society; } \\
\text { the newest branch of economic science, studying the effective use of modern } \\
\text { information technologies in the field of electronic data; } \\
\text { economic theory of the information society }\end{array}$ \\
\hline Information environment & $\begin{array}{l}\text { environment that exists through digital telecommunication networks; } \\
\text { information environment conducive to the development of information and } \\
\text { communication technologies; } \\
\text { some kind of virtual environment addition }\end{array}$ \\
\hline $\begin{array}{c}\text { System of economic } \\
\text { relations }\end{array}$ & $\begin{array}{l}\text { network, system-organized spatial structure of relationships between business } \\
\text { entities; } \\
\text { total social relations emerging when using electronic technologies and electronic } \\
\text { infrastructure; } \\
\text { structure based on effective information management of the production system }\end{array}$ \\
\hline Business profile & $\begin{array}{l}\text { type of economic activity that is carried out using information and } \\
\text { communication technologies; } \\
\text { automated business management based on advanced information technologies; } \\
\text { economic activity in which the key factor in production is digital data; } \\
\text { production of goods and services using information technologies }\end{array}$ \\
\hline Instrument & instrument to reduce transaction expenses \\
\hline
\end{tabular}


Based on the conceptual provisions and own research results (Kwilinski \& Trushkina, 2019; Kwilinski, Trushkina \& Rynkevich, 2019; Kwilinski, 2018a; 2018b; 2018c; 2019), it is proposed to use the term "information economy" as a system of economic relations using modern information technologies, as well as the information environment, which is effectively developing with the help of digital technologies and the functioning of information infrastructure facilities (Figure 2).

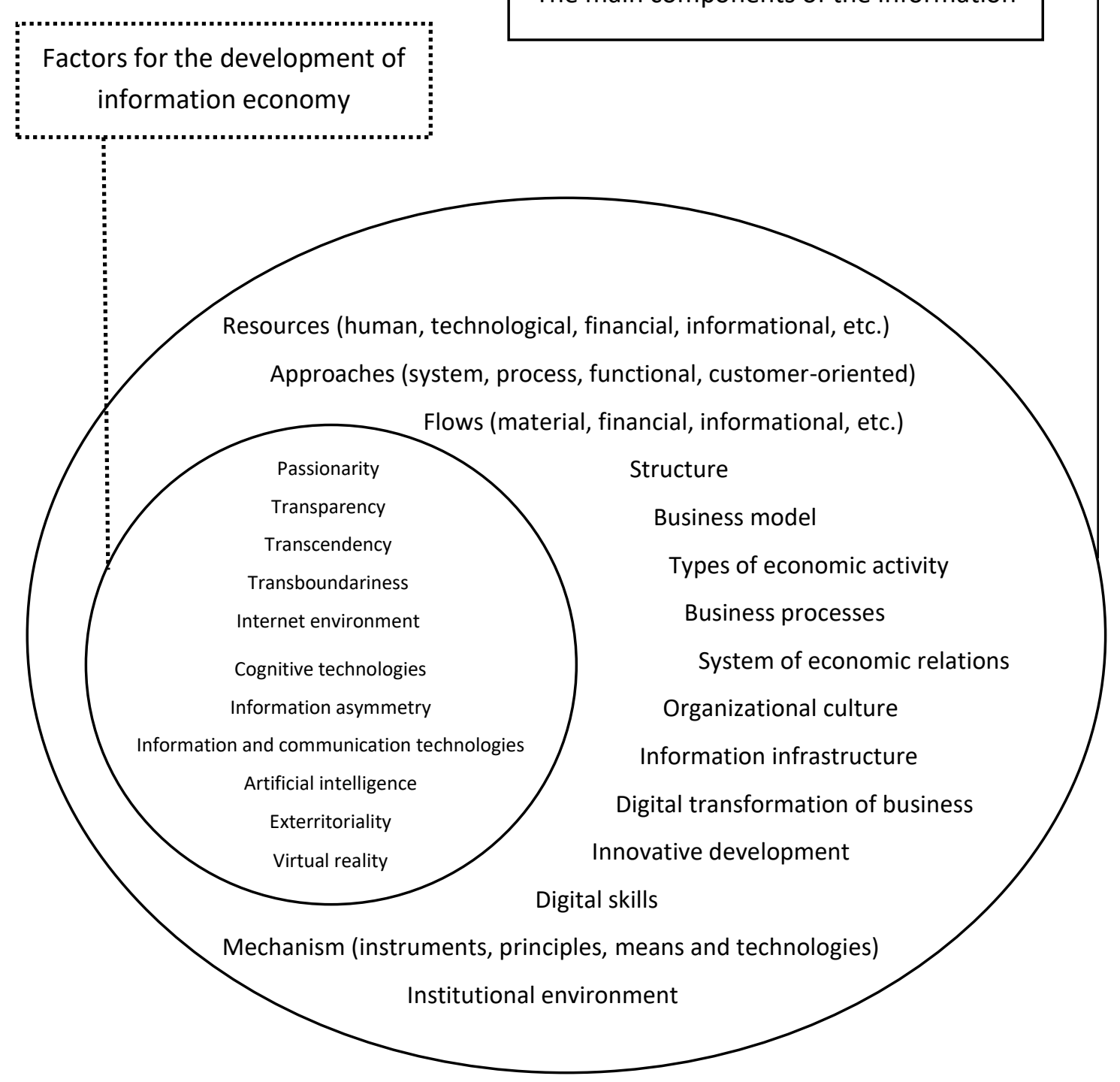

Figure 2. The informatory structure of the information economy Source: own research.

It is found that the development of the information economy is influenced by many factors that can be conditionally systematized into 5 groups: 


$$
F=\left\{\begin{array}{c}
F_{1}\left(x_{11}, x_{12}, x_{13}, x_{14}, x_{15}, x_{16}\right) ; \\
F_{2}\left(x_{21}, x_{22}, x_{23}\right) ; \\
F_{3}\left(x_{31}, x_{32}, x_{33}, x_{34}, x_{35}, x_{36}, x_{37}\right) ; \\
F_{4}\left(x_{41}, x_{42}, x_{43}, x_{44}, x_{45}, x_{46}, x_{47}, x_{48}, x_{49}\right) ; \\
F_{5}\left(x_{51}, x_{52}\right)
\end{array}\right\}
$$

where $F_{1}$-research and development in the field of information and communication technologies (ICT);

$x_{11}$ - research and development costs in the area of "Information and Telecommunications";

$x_{12}$ - authors' publications in the journals indexed by Scopus and Web of Science, in the areas of ICT;

$x_{13}$ - indices of scientific specialization of the countries according to the publications in editions indexed in Scopus and Web of Science, in the areas of ICT;

$x_{14}$ - patent activity of applicants in the field of ICT;

$x_{15}$-share of each country in the global number of patent applications in the field of ICT;

$x_{16}$ - development of advanced manufacturing technologies related to ICT;

$F_{2}$ - employee component;

$x_{21}$ - share of ICT specialists of the highest skill level in the total number of employees by country;

$x_{22}$ - the number of ICT specialists by the qualification level;

$x_{23}$ - the number of ICT specialists by the type of economic activity;

$F_{3}$ - development of the ICT sector;

$x_{31}$ - the share of the ICT sector in the number of people employed in the business sector by country;

$x_{32}$ - the share of the ICT sector in the gross value added of the business sector by country;

$x_{33}$ - innovative activity of organizations in the ICT sector;

$x_{34}$ - costs of innovations of organizations in the ICT sector, including technological, marketing, organizational innovations;

$x_{35}$ - business activity of organizations providing services in the field of information technologies (demand for services, the number of contracts concluded, the cost of services rendered, prices for services, number of employees, competitiveness, investments, economic status of organizations);

$x_{36}$ - the export structure of goods (services) in the field of ICT in the global volume of export of goods (services);

$x_{37}$ - the import structure of goods (services) in the field of ICT in the global volume of import of goods (services);

$F_{4}$ - digital technologies in business;

$x_{41}-$ broadband Internet access in organizations by country (in $\%$ of the total number of organizations in the business sector);

$x_{42}$ - the intensity of the use of digital technologies in organizations (broadband Internet; "cloud" services; RFID technologies, CRM-, ERP-, SCM-systems; electronic sales);

$x_{43}$ - Internet access in organizations; 
$x_{44}$ - the presence of a website in organizations;

$x_{45}$ - using of electronic data exchange technologies between internal and external information systems in organizations;

$x_{46}$ - application of software in organizations;

$x_{47}$ - the use of the Internet in organizations to communicate with suppliers according to the purposes;

$x_{48}$ - electronic purchases and sales in organizations;

$x_{49}$ - cost structure of organizations for the implementation of ICT;

$F_{5}$ - information security;

$x_{51}$ - the population's collision with the problem of virus infection when using the Internet and with threats to information security when using the Internet;

$x_{52}$ - using of information security means in organizations.

\section{Results}

Key factors for evaluating the development of the information economy are:

$$
\text { Oc }=\sum_{i=1}^{n} y_{i} \rightarrow \max
$$

where $O c-$ evaluation of the development of the information economy;

$y_{1}-$ GDP volume;

$y_{2}$ - total information product;

$y_{3}-$ the number of Internet users (per 1000 people);

$y_{4}-$ R\&D expenses (in \% to GDP);

$y_{5}$ - expenses on education (in \% to GDP);

$y_{6}-$ GDP information capacity (the amount of information generated per 1 monetary unit of GDP);

$y_{7}$ - total Internet income;

$y_{8}$ - softification coefficient of the economy, which shows an increase in the information capacity of industries, due to an increase in the share of non-material costs in gross output;

$y_{9}$ - the share of labor resources employed in the information sector;

$y_{10}$ - the share of labor resources employed in an innovative economy;

$y_{11}$ - networked readiness index;

$y_{12}$ - index of the information society;

$y_{13}$ - human development index;

$y_{14}$ - index of development of the society intellectual potential;

$y_{15}$ - index of society informational support;

$y_{16}$ - the creation of high-performance job opportunities.

Prospective lines of development of the information economy in the context of global digital transformations include:

- big data: in 2018, 50\% of large companies received income from Data-as-a-Service; the volume of global IP-traffic will grow in 2016-2021 in 2.9 times (Figure 3); 44 zettabytes of global volume of generated data by 2020 (4.4 zettabytes in 2013); \$ 90 billion - volume of global big data market in 2025 ( $\$ 22.6$ billion in 2015); 


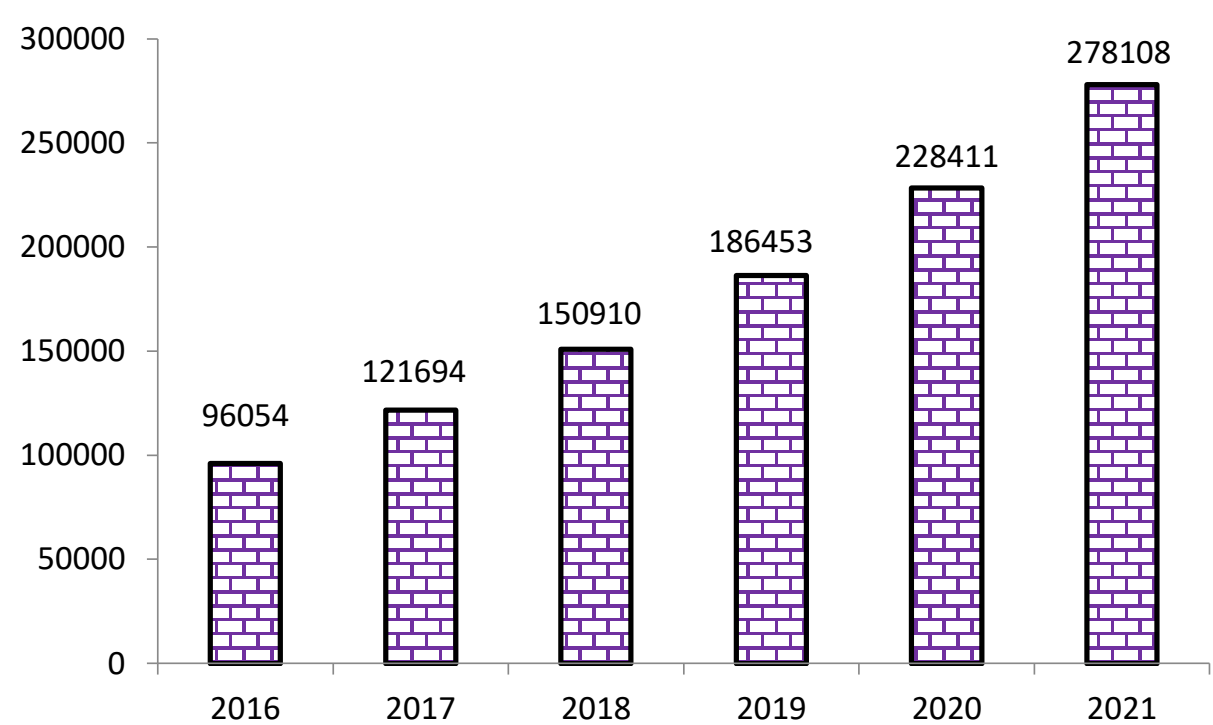

Figure 3. The dynamics of the world IP-traffic volume, petabytes

Source: own research on the basis of the World Economic Forum data, Accenture, Allied Market Research, BCG, IDC, ResearchGate, Telecompetitor, Tractica.

- quantum technologies: 1 billion euros is planned to be allocated for the implementation of the Quantum Flagship program in the EU; $25 \%$ of the average annual growth rate of the quantum computing market in 2018-2024;

- components of robotics and sensorics: $10 \%$ average annual growth rate of the global robotics market for 2010-2025, including by sector: industrial - 7.6\%, defense - 7.7\%, commercial - $13.2 \%$, consumer - $21,9 \%$; 5 million jobs will be replaced by 2020 by robots; $25 \%$ average level of robotization in industry by 2025; $\$ 87$ billion - volume of the global robotics market in 2025;

- neurotechnologies and artificial intelligence: the market volume for artificial intelligence will increase in 2016-2025 in 42.6 times (Figure 4); 2.3 million jobs will be created by 2020 thanks to artificial intelligence; $20 \%$ of employees engaged in non-routine tasks will rely on the help of artificial intelligence by $2022 ; 85 \%$ of customer interactions will be managed using artificial intelligence by $2025 ; \$ 15.7$ trillion - global GDP growth thanks to artificial intelligence by 2030 ;

- new production technologies: the global market volume for smart materials will increase in 2014-2022 in 2.2 times (Figure 5); $\$ 40$ billion - the global market volume for smart factories; $\$ 550$ billion - 3D printing contribution to the global economy by 2025;

- industrial Internet: \$21.5 billion - the global market volume for the Internet of robotic things in 2022; 500 million objects of production and logistics chains will be connected to the industrial Internet of things by 2025;

- blockchain: 33\% average cryptocurrency capitalization rate in 2017-2023; \$ 20 billion bank savings from using blockchain technology in 2022; $10 \%$ of global GDP will be stored on blockchain networks in 2027; 


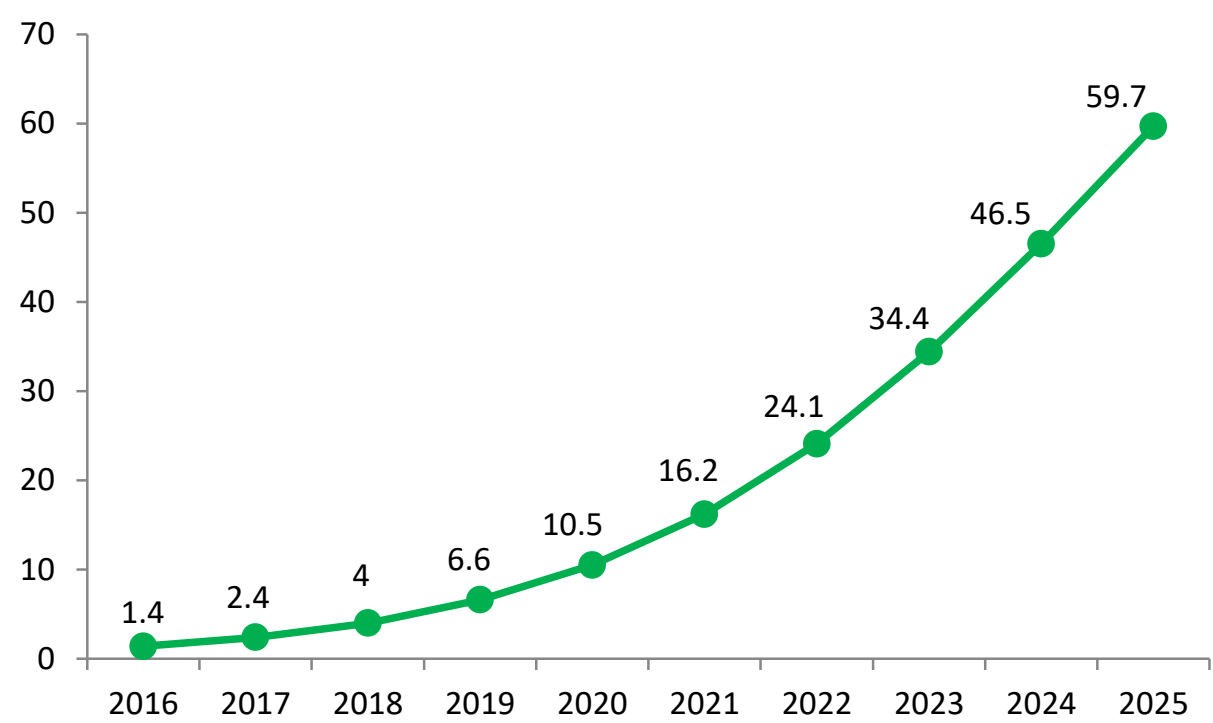

Figure 4. Dynamics of the artificial intelligence market volume, billion US dollars

Source: own research on the basis of the World Economic Forum data, Accenture, Allied Market Research, BCG, IDC, ResearchGate, Telecompetitor, Tractica.

- wireless communication technologies: the number of connected devices in the world will increase in 2017-2022 in 1.6 times (wired connection) and in 4.9 times (wireless, LPWAN); 50\% of the world's population will have Internet access in 2019; 85\% coverage of the Earth with wireless Internet access in 2021; $\$ 16$ billion - the global market volume for wireless routers in 2025;

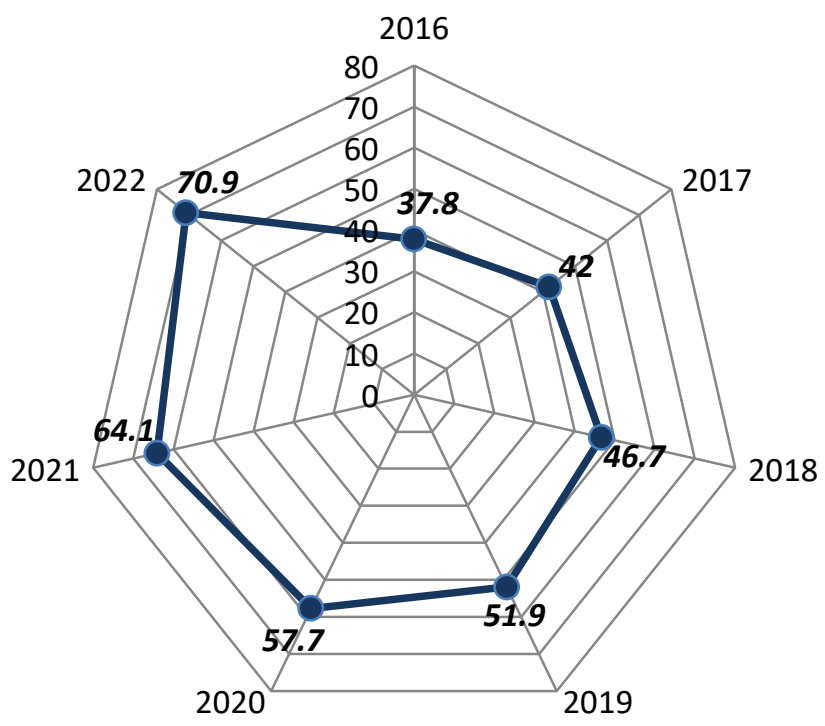

Figure 5. Dynamics of the global market volume for smart materials, billion US dollars Source: own research on the basis of the World Economic Forum data, Accenture, Allied Market Research, BCG, IDC, ResearchGate, Telecompetitor, Tractica. 
- virtual and augmented reality technologies: the global market volume for augmented and virtual reality will increase in 2016-2021 in 35.2 times (Figure 6).

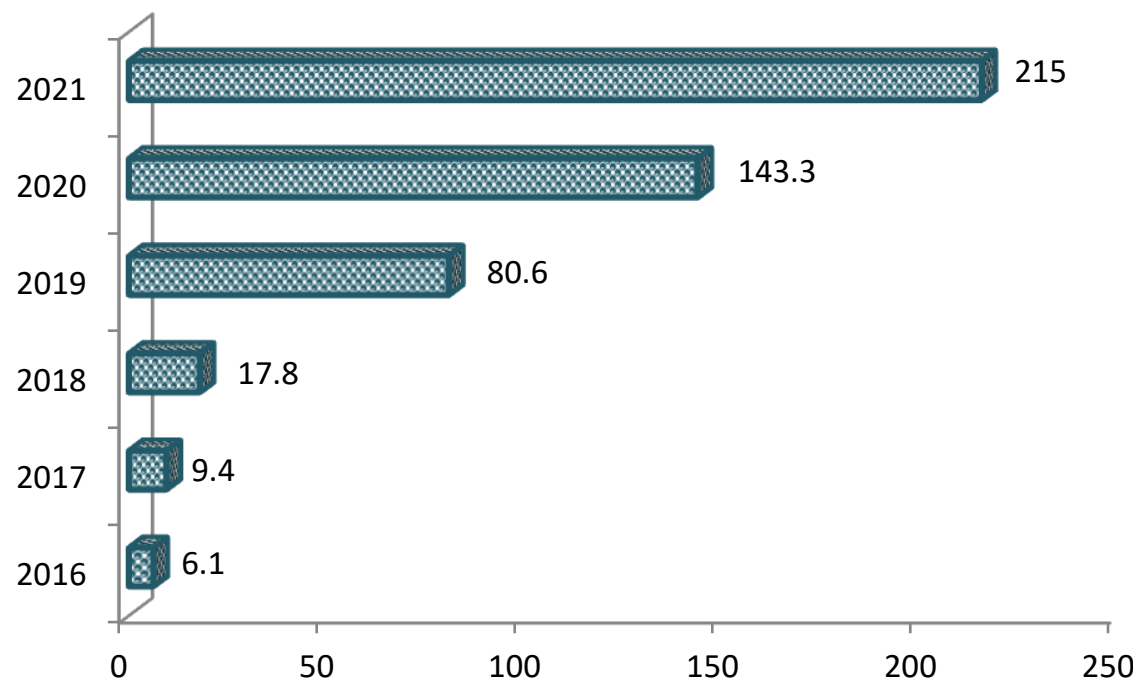

Figure 6. The dynamics of the global market volume for augmented and virtual reality, billion US dollars

Source: own research on the basis of the World Economic Forum data, Accenture, Allied Market Research, BCG, IDC, ResearchGate, Telecompetitor, Tractica.

The effect of the implementation of prospective lines of the information economy development can be calculated using the formula below:

$$
E=\sum\left(\begin{array}{c}
A\left(a_{1}, a_{2}, a_{3}, a_{4}, a_{5}, a_{6}\right) ; \\
B\left(b_{1}, b_{2}, b_{3}, b_{4}, b_{5}\right) ; \\
C\left(c_{1}, c_{2}, c_{3}, c_{4}, c_{5}\right) ; \\
D\left(d_{1}, d_{2}, d_{3}, d_{4}, d_{5}\right) ; \\
G\left(g_{1}, g_{2}, g_{3}, g_{4}, g_{5}, g_{6}\right) ; \\
H\left(h_{1}, h_{2}, h_{3}, h_{4}\right) ; \\
K\left(k_{1}, k_{2}, k_{3}, k_{4}, k_{5}, k_{6}\right) ; \\
L\left(l_{1}, l_{2}, l_{3}, l_{4}, l_{5}\right) ; \\
M\left(m_{1}, m_{2}, m_{3}, m_{4}\right)
\end{array}\right) \rightarrow \max
$$

where $A$ - Big Data;

$a_{1}$ - expanding the capabilities of processing unstructured data;

$a_{2}$ - increasing the processing rate of large data arrays;

$a_{3}$ - severization of requirements for standards for the collection, storage and processing of data;

$a_{4}$ - tightening personal data protection standards;

$a_{5}$ - development of predictive analytics;

$a_{6}$ - creation of new job opportunities; 
$B$ - quantum technologies;

$b_{1}$ - creation of new, almost unbreakable forms of encryption;

$b_{2}$ - solution of specialized tasks requiring extremely reliable calculations;

$b_{3}$ - processing huge amounts of data in large databases;

$b_{4}$ - replacement of common computers, the computing power of which will reach the physical limit in the near future;

$b_{5}$ - appearance of artificial intelligence technologies and computer-aided learning on a new level;

$C$-components of robotics and sensorics;

$c_{1}$ - significant increase in labor productivity and the replacement of people in routine operations;

$c_{2}$ - minimizing the number of accidents at production site;

$c_{3}$-optimization of business processes, achieving production flexibility;

$c_{4}$ - reduction of energy costs, increasing of energy efficiency;

$C_{5}$ - monitoring of online production;

$D$ - neurotechnologies and artificial intelligence;

$d_{1}$ - expanding the capabilities of automation and robotization of manual labor;

$d_{2}$ - exclusion of subjectivity and irrationality in decision making;

$d_{3}$ - restructuring the global labor market;

$d_{4}$ - emergence of new forms of legal relations between robots and people;

$d_{5}$ - transformation of educational processes in favor of personalization and the development of conceptual thinking;

$G$ - new production technologies;

$g_{1}$-creation of high-tech job opportunities;

$g_{2}$ - minimization of negative impact on the environment;

$g_{3}$-increasing the quality of products and reducing the time it takes to place on market;

$g_{4}$-improving the quality of life of the population;

$g_{5}$-reduction of production costs;

$g_{6}$ - increase in the level of customization of products and services;

$H$-industrial Internet;

$h_{1}$ - growth of energy efficiency of the economy;

$h_{2}$ - displacement of low-skilled labor;

$h_{3}$ - acceleration of product entry into market;

$h_{4}$ - reduction of capital costs for maintenance, support and updating of IT systems;

$K$ - blockchain;

$k_{1}$ - improving transaction security and data storage;

$k_{2}$ - minimizing the number of intermediaries in the financial sector;

$k_{3}$ - mass use of P2P transfers;

$k_{4}$ - development of cryptography;

$k_{5}-$ simplification of international transfers and modernization of the currency exchange market;

$k_{6}$ - starting the use of a pricing model after the transaction (consumption);

$L$ - wireless communication technologies;

$l_{1}$ - removal of geographical barriers; 
$l_{2}$ - increasing the availability of information;

$l_{3}-$ minimization of energy costs;

$l_{4}$ - the development of the Internet of things;

$l_{5}$ - the prevalence of the online format of social interactions;

$M$ - virtual and augmented reality technologies;

$m_{1}$ - predictive maintenance services;

$m_{2}$ - optimization of production processes;

$m_{3}$ - training of specialists in applied areas on a virtual basis;

$m_{4}$ - development of the virtual native advertising segment.

\section{Conclusions}

The rapid development of digital technologies and the emergence of platform solutions lead to the formation of the concept of information economy. The study has found that most researchers identify the information economy with concepts such as digital economy, new economy, post-industrial economy, virtual economy, network economy, information and network economy, electronic economy, digital intellectual economy, Internet economy, eeconomy, network economy, web economy, knowledge economy, Industry 4.0, electromobility, emergent economy, spatial economy, gig economy or work-for-yourself economy, mathematical economy (game theory).

Scientific approaches to the definition of terminology with the problems of the development of the information economy are conventionally systematized into classification groups: science; a new type of economy; section of economic theory; information environment; system of economic relations; type of economic activity; instrument.

As a result of generalization of existing scientific developments on the conceptual apparatus and analysis of its compliance with modern business conditions, the meaning of the concept of "information economy" as a system of economic relations using modern information technologies, as well as the information environment, which is effectively developed using digital technologies and the functioning of information infrastructure facilities, has been clarified.

It was found that the development of the information economy is influenced by many factors that are conditionally classified into five groups: research and development in the field of ICT; employee component; ICT sector development; digital technologies in business; information security.

The modern concepts of the information economy include:

- creation of a digital platform as a new business model, the essence of which is to provide business and the public with a specific service for coordinating the activities of various market participants. The platform allows sellers and buyers of goods (services) to quickly find each other, close a deal and perform settlements. Digital platforms are mainly used in commercial and logistics activities. The functioning of these platforms accelerates and reduces the cost of 
production and exchange processes, eliminates unnecessary intermediary links, and improves the efficiency of markets;

- use of the concept "Industry 4.0" and the "smart factory" as drivers for the digital development of industry;

- implementation of the concept of "cyber-physical system" as a single complex of computing resources, information systems and physical processes. This system includes: a supplier-client integration system in a single control loop for continuity business processes and data exchange; industrial robots and computer vision systems coordinating their interaction; 3D printing for prototyping and manufacturing of small batches at local sites; AR and VR technologies for creating visual "instructions-recommendation" at workplaces, as well as for promoting and selling products; computer-aided design systems CAD/ CAE; "big data" analysis to support online decision making.

It should be noted that the implementation of qualitatively new digital technologies is a necessary but not sufficient condition for the effective development of the information economy. These technologies should bring a significant positive economic effect: increase productivity by increasing production volumes and reduce the amount of resources used for production. For such an increase in the level of productivity, it is advisable to comprehensively transform the business, in which the use of digital technologies is accompanied by improved management. It should be emphasized that in most cases, the digital transformation of the business gives positive results in the long term, since the initial investment in technological and associated changes therewith represents significant costs that will be compensated for a long period of time. As the results of a study by Capgemini Consulting and MIT Sloan School of Management (2015) showed, the digital transformation process cannot be completely ignored. This is due to the fact that the decrease in profit in this case compared to competitors will be $24 \%$ per year. It is proved that the profit of companies grows by an average of $26 \%$, if technologies and new management methods are used together. If only to improve management without resorting to digital technologies, then the profit of companies is growing by $9 \%$. If you invest only in technologies, not paying attention to the necessary changes in management, profit does not grow at all, but falls by $11 \%$.

Thus, the use of digital technologies improves the business and investment climate by increasing the availability and efficiency of public services, effective management in companies, transparency of conditions of business operations (electronic platforms for tendering and procurement, feedback portals), as well as the development of an ecosystem of business services (logistics services, mobile banking).

In further studies, it is necessary to pay attention to the development of economic and mathematical modeling using factor analysis and the determination of strategic development benchmarks of the information economy; development a methodological approach to evaluating the effect of the implementation of information economy development strategies; improvement of the management system of the logistics activities of enterprises using information and communication and cognitive technologies. 


\section{References}

Apalkova, V. V. (2015). Kontseptsiia rozvytku tsyfrovoi ekonomiky v Yevrosoiuzi ta perspektyvy Ukrainy [Concept of digital economy development in the European Union and prospects of Ukraine]. Visnyk Dnipropetrovskoho universytetu. Seriia: Menedzhment innovatsii - Bulletin of the Dnipropetrovsk University. Series: Innovation management, 4, 9-18 [in Ukrainian].

Bahl, M. (2016). The Work Ahead: The Future of Businesses and Jobs in Asia Pacific's Digital Economy. Retrieved from https://www.cognizant.com/white-papers/the-work-ahead-the-future-of-businessandjobs-in-asia-pacifics-digital-economy-codex2255.pdf

Baranov, D. N. (2018). Sushchnost' i soderzhanie kategorii "tsifrovaya ekonomika» [The essence and content of the digital economy category]. Vestnik Moskovskogo universiteta. Seriia: Ekonomika $i$ upravlenie - Bulletin of Moscow University. Series: Economics and Management, 2, 15-23 [in Russian].

Belikova, K. M. (2018). Tsifrovaya intellektual'naya ekonomika: ponyatie i osobennosti pravovogo regulirovaniya (teoreticheskiy aspekt) [Digital intellectual economy: concept and features of legal regulation (theoretical aspect)]. Nauka $i$ obrazovanie: khozyaystvo $i$ ekonomika, predprinimatel'stvo, pravo i upravlenie - Science and education: economy and economics, entrepreneurship, law and management, 8(99), 82-85 [in Russian].

Bilotserkivets, V. V. (2015). Nova ekonomika: istoriia ta suchasnist u definityvnomu vymiri [The New Economy: History and the Present in the Definitive Dimension]. Investytsii: praktyka ta dosvid Investment: practice and experience, 5, 9-13 [in Ukrainian].

Boden, M., Cagnin, C., Carabias, V., \& Haegeman, K. (2010). Facing the future: time for the EU to meet global challenges. European Commission Joint Research Centre Institute for Prospective Technological Studies European Union. Retrieved from http://www.et2050.eu/docs/2010-IPTS_ Facing_the_Future.pdf.

Brynjolfsson, E., \& Kahin, B. (2000). Introduction. Understanding the Digital Economy, (pp. 1-10). Cambridge: MIT Press.

Brynjolfsson, E., \& Kahin, B. (2000). Understanding the Digital Economy: Data, Tools, and Research. Cambridge: MIT Press.

Bukh, R., \& Heeks, R. (2017). Defining, Conceptualizing and Measuring the Digital Economy. Global Development Institute working papers, 68. Retrieved from https://diodeweb.files. wordpress.com/2017/08/diwkppr68-diode.pdf.

Chumachenko, N. E. (2014). Informatsionnaya ekonomika i novaya ekonomika: obshchee i osobennoe, ponyatiynyy apparat i soderzhanie [Information economy and the new economy: general and special, conceptual apparatus and content]. Vestnik Saratovskogo gosudarstvennogo sotsial'noekonomicheskogo universiteta - Bulletin of Saratov State Socio-Economic University, 7, 35-39 [in Russian].

Dahlman, C., Mealy, S., \& Wermelinger, M. (2016). Harnessing the Digital Economy for Developing Countries. Paris: OECD. Retrieved from http://www.oecd-ilibrary.org/docserver/download/ 4adffb24-en.pdf. 
Dashchenko, Yu. Yu. (2018). Tsifrovaya ekonomika kak ekonomika budushchego [Digital economy as the economy of the future]. Tendentsii razvitiya nauki i obrazovaniya - Trends in the development of science and education, 35(1), 18-19 [in Russian].

Dyatlov, S. A., Maryanenko, V. P., \& Selishcheva, T. A. (2016). Informatsionno-setevaya ekonomika: struktura, dinamika, regulirovanie [Information and network economy: structure, dynamics, regulation]. Moscow: INFRA-M [in Russian].

Dźwigoł, H. (2019). Research methods and techniques in new management trends: research results. Virtual Economics, 2(1), 31-48. https://doi.org/10.34021/ve.2019.02.01(2)

Elmasry, T., \& et al. (2016). Digital Middle East: Transforming the Region into a Leading Digital Economy. New York: McKinsey \& Company. Retrieved from http://www.mckinsey.com/globalthemes/middle-east-and-africa/digital-middle-east-transforming-the-region-into-a-leading-digitaleconomy.

Gronlund, L. (1898). The New Economy. A Peaceable Solution of the Social Problem. Chicago, New York: Herbert S. Stone \& Company.

Gudz, O. Ye. (2018). Tsyfrova ekonomika: zmina tsinnostei ta oriientyriv upravlinnia pidpryiemstvamy [The Digital Economy: Changing the Values and Landmarks of Enterprise Management]. Ekonomika. Menedzhment. Biznes - Economy. Management. Business, 2(24), 4-12 [in Ukrainian].

Hasanov, T. A., \& Hasanov, G. A. (2017). Tsifrovaya ekonomika - kak novoe napravlenie ekonomicheskoy teorii [Digital economy - as a new area of economic theory]. Regional'nye problemy preobrazovaniya ekonomiki - Regional problems of economic transformation, 6(80), 4-10 [in Russian].

Ivanov, V. V., \& Malinetskiy, G. G. (2017). Tsifrovaya ekonomika: ot teorii k praktike [Digital economy: from theory to practice]. Innovatsii - Innovation, 12, 3-12 [in Russian].

Kit, L.Z. (2014). Evoliutsiia merezhevoi ekonomiky [Evolution of network economy]. Visnyk Khmelnytskoho natsionalnoho universytetu. Seriia: Ekonomichni nauky - Bulletin of Khmelnitsky National University. Series: Economic sciences, 2(3), 187-194 [in Ukrainian].

Knickrehm, M., Berthon, B., \& Daugherty, P. (2016). Digital Disruption: The Growth Multiplier. Dublin: Accenture. Retrieved from https://www.accenture.com/_acnmedia/PDF-4/Accenture-StrategyDigital-Disruption Growth-Multiplier.pdf.

Koliadenko, S. V. (2016). Tsyfrova ekonomika: peredumovy ta etapy stanovlennia v Ukraini i u sviti [The Digital Economy: Prerequisites and Stages of Formation in Ukraine and in the World]. Ekonomika. Finansy. Menedzhment: aktualni pytannia nauky i praktyky - Economy. Finances. Management: topical issues of science and practice, 6, 105-112 [in Ukrainian].

Kuzior, A., Kwilinski, A., \& Tkachenko, V. (2019). Sustainable development of organizations based on the combinatorial model of artificial intelligence. Entrepreneurship and Sustainability, 7(2), 1353-1376. http://doi.org/10.9770/jesi.2019.7.2(39)

Kwilinski, A. (2018a). Mechanism of modernization of industrial sphere of industrial enterprise in accordance with requirements of the information economy. Marketing and Management of Innovations, 4, 116-128. http://doi.org/10.21272/mmi.2018.4-11 
Kwilinski, A. (2018b). Trends of development of the informational economy of Ukraine in the context of ensuring the communicative component of industrial enterprises. Economics and Management, 1(77), 64-70.

Kwilinski, A. (2018c). Mechanism of formation of industrial enterprise development strategy in the information economy. Virtual Economics, 1(1), 7-25. https://doi.org/10.34021/ve.2018.01.01(1)

Kwilinski, A. (2019). Implementation of Blockchain Technology in Accounting Sphere. Academy of Accounting and Financial Studies Journal, 23(SI2), 1528-2635-23-SI-2-412: 1-6. Retrieved from https://www.abacademies.org/articles/Implementation-of-Blockchain-Technology-in-AccountingSphere-1528-2635-23-SI-2-412.pdf

Kwilinski, A., \& Trushkina, N. (2019). Informational economy in the global digital environment: trends and development priorities. Education, Law, Business, (pp. 20-23). Cartero Publishing House, Madrid, Spain.

Kwilinski, A., Dalevska, N., Kravchenko, S., Hroznyi, I., Kovalenko, I. (2019b). Formation of the entrepreneurship model of e-business in the context of the introduction of information and communication technologies. Journal of Entrepreneurship Education, 22(SI1), 1528-2651-22-S1-337: 1-7. Retrieved from https://www.abacademies.org/articles/Formation-of-the-entrepreneurshipmodel-of-e-business-1528-2651-22-S1-337.pdf

Kwilinski, A., Volynets, R., Berdnik, I., Holovko, M., \& Berzin, P. (2019c). E-Commerce: Concept and Legal Regulation in Modern Economic Conditions. Journal of Legal, Ethical and Regulatory Issues, 22(SI2), 1544-0044-22-SI-2-357: 1-6. Retrieved from https://www.abacademies.org/articles/E-Commerceconcept-and-legal-regulation-in-modern-economic-conditions-1544-0044-22-SI-2-357.pdf

Kwilinski, A., Tkachenko, V., Kuzior, A. (2019d). Transparent cognitive technologies to ensure sustainable society development. Journal of Security and Sustainability Issues, 9(2), 561-570 http://doi.org/10.9770/jssi.2019.9.2(15)

Kwilinski, A., Trushkina, N., \& Rynkevich, N. (2019). Kontseptual'nye podkhody k opredeleniyu termina "Informatsionnaya ekonomika" [Conceptual Approaches to Defining the Term "Information Economy"]. Problemy ekonomiki - The Problems of Economy, 3, 147-155. https://doi.org/10.32983/2222-0712-2019-3-147-155 [in Russian].

Lakhno, V., Malyukov, V., Bochulia, T., Hipters, Z., Kwilinski, A., \& Tomashevska, O. (2018). Model of managing of the procedure of mutual financial investing in information technologies and smart city systems. International Journal of Civil Engineering and Technology, 9(8), 1802-1812. Retrieved from http://www.iaeme.com/MasterAdmin/UploadFolder/IJCIET_09_08_181/IJCIET_09_08_181.pdf

Lane, N. (1999). Advancing the digital economy into the 21st century. Information Systems Frontiers, $1(3), 317-320$.

Liashenko, V. I., \& Vishnevskyi, O. S. (2018). Tsyfrova modernizatsiia ekonomiky Ukrainy yak mozhlyvist proryvnoho rozvytku [Digital modernization of the Ukrainian economy as an opportunity for breakthrough development]. Kyiv: Institute of Industrial Economics of NAS of Ukraine [in Ukrainian].

Machlup, F. (1962). The Production and Distribution of Knowledge in the United States. Princeton, New Jersey: Princeton University Press.

Machlup, F. (1973). The Production and Distribution of Knowledge in the United States. New Jersey, Princeton. 
Machlup, F. (2014). Knowledge: Its Creation, Distribution and Economic Significance. In Knowledge and Knowledge Production. New Jersey: Princeton.

Margherio, L., \& et al. (1999). The Emerging Digital Economy. Washington, DC: Department of Commerce. Retrieved from http://www.esa.doc.gov/sites/default/files/emergingdig_0.pdf.

Matveeva, I. V., \& Khomenko, E. B. (2017). Stanovlenie kontseptual'nykh polozheniy teorii informatsionnoy ekonomiki: metodologicheskie i prakticheskie aspekty [Formation of the conceptual provisions of the theory of information economy: methodological and practical aspects]. Vestnik PNIPU. Sotsial'no-ekonomicheskie nauki - Bulletin of PNIPU. Socio-economic sciences, 1 , 136-146. http://doi.org/10.15593/2224-9354/2017.1.11 [in Russian].

MIT Sloan Management Review, Strategy, Not Technology, Drives Digital Transformation - Becoming a Digitally Mature Enterprise (2015).

Mesenbourg, T.L. (2001). Measuring the Digital Economy, US Bureau of the Census, Suitland. https://www.census.gov/content/dam/Census/library/working-papers/2001/econ/umdigital.pdf.

Pająk, K., Kamińska, B., \& Kvilinskyi, O. (2016). Modern trends of financial sector development under the virtual regionalization conditions. Financial and Credit Activity: Problems of Theory and Practice, 2(21), 204-217. https://doi.org/10.18371/fcaptp.v2i21.91052

Panshin, B. (2016). Tsifrovaya ekonomika: osobennosti i tendentsii razvitiya [Digital economy: features and development trends]. Nauka i innovatsii - Science and innovation, 3(157), 17-20 [in Russian].

Pashkus, V. Yu. (2006). Novaya ekonomika: ponyatie i prichiny vozniknoveniya. Stanovlenie informatsionnoy ekonomiki: teoriya i praktika [New economy: concept and causes. The formation of the information economy: theory and practice], (pp. 24-27). St. Petersburg: Nestor [in Russian].

Pidoymo, L.P., \& Buturlakina, E.V. (2010). Suschnost kategoriy «informatsionnoe obschestvo», «informatsionnaya ekonomika» [The Essence of Definitions «Information Society» and «Information Economy»]. Sovremennaya ekonomika: problemyi i resheniya-Modern Economics: Problems and Solutions, 4(4), 112-118. Retrieved from https://meps.econ.vsu.ru/meps/article/view/824/431 [in Russian].

Porat, M.U. (1977). The information economy: definition and measurement. Washington: U.S. Dept. of Commerce, Office of Telecommunications.

Shkarlet, S. N. (2014). Informatsionnaya ekonomika kak osnova sotsial'no-ekonomicheskoy regeneratsii Ukrainy [Information economy as the basis of socio-economic regeneration of Ukraine]. Ekonomika Ukrainy - Economy of Ukraine, 11(628), 51-60 [in Russian].

Tapscott, D. (1996). The Digital Economy: Promise and Peril in the Age of Networked Intelligence. New York: McGraw-Hill.

Tapscott, D., \& Williams, E.D. (2009). Wikinomics: How Mass Collaboration Changes Everything. New York: BestBusinessBooks.

Teslenko, I. B., \& et al. (2016). Tsifrovaya ekonomika [Digital economy]. Moscow: Rusains [in Russian].

Tkachenko, V., Kwilinski, A., Klymchuk, M., \& Tkachenko, I. (2019a). The economic-mathematical development of buildings construction model optimization on the basis of digital economy. Management Systems in Production Engineering, 27(2), 119-123. http://doi.org/10.1515/mspe2019-0020 
Tkachenko, V., Kwilinski, A., Korystin, O., Svyrydiuk, N., Tkachenko, I. (2019b). Assessment of information technologies influence on financial security of economy. Journal of Security and Sustainability, 8(3), 375-385. http://doi.org/10.9770/jssi.2019.8.3(7)

Tkachenko, V., Kwilinski, A., Tkachenko, I., \& Puzyrova, P. (2019c). Theoretical and methodical approaches to the definition of marketing risks management concept at industrial enterprises. Marketing and Management of Innovations, 2, 228-238. http://doi.org/10.21272/mmi.2019.2-20

Tkachenko, V., Kuzior, A., \& Kwilinski, A. (2019d). Introduction of artificial intelligence tools into the training methods of entrepreneurship activities. Journal of Entrepreneurship Education, 22(6), 1-10. Retrieved from https://www.abacademies.org/articles/Introduction-of-artificial-intelligence-tools1528-2651-22-6-477.pdf

Tugui, A. (2015). Meta-Digital Accounting in the Context of Cloud Computing. Encyclopedia of Information Science and Technology (3rd ed.), (pp. 20-32). USA: IGI Global. 